\title{
Detection of Visceral adiposity by Ultrasonography and its relation to insulin resistance in $\mathrm{HCV}$ patients
}

\author{
Mostafa K.Mohamed ${ }^{1}$,Gamal Esmat ${ }^{2}$, Mohamed Said² , Mohamed Abdel- \\ Hamid $^{3}$,Mohamed Hassany ${ }^{4}$,Mohamad A.Hassanein ${ }^{4}$, Kamal A.El- Atrebi ${ }^{4}$
}

\author{
1-Department of Community, Environmental and Occupational Medicine, Faculty of Medicine, Ain \\ Shams University. \\ 2-Department of Tropical Medicine, Cairo University. \\ 3-Viral Hepatitis Research Laboratory, National Hepatology and Tropical Medicine Research Institute \\ 4- Department of Tropical Medicine, National Hepatology and Tropical Medicine Research Institute.
}

\begin{abstract}
Background: Hepatitis $\mathrm{C}$ is a major cause of liver-related morbidity and mortality and represents a major public health problem in Egypt and worldwide. Ultrasonography is a simple non-invasive method for detection of visceral fat, which is directly, correlated with insulin resistance (IR) as well as development of type 2 diabetes mellitus.
\end{abstract}

Aim: To assess the validity of detection of visceral adipose tissue area with Ultrasonography and its correlation with IR in HCV patients

Materials \& Method: The study participants were subcategorized into two groups, Group (I): included 867 healthy subjects with negative (HCV) RNA as a control group. Group (II): included 277 patients with chronic HCV as a study group. The 2 groups were subjected to thorough history taking, full clinical examination, Anthropometric study,ultrasonographic examination and laboratory investigations including liver functions, viral markers, and qualitative PCR for HCV RNA, lipid profile \& glucose profile .

Results: This study revealed that ultrasonography is a simple, non-invasive, safe method in detection of visceral adiposity, which is correlated significantly with IR in chronic HCV patients.

Key words: HCV-Insulin resistance-Ultrasonography-Visceral adiposity.

\section{Introduction:}

Epidemiological studies often report an association between severe obesity and mortality due to increased rates of cardiovascular and cerebrovascular diseases and diabetes (Feinleib,.1985). In moderate obesity, regional distribution appears to be an important indicator for metabolic and cardiovascular alterations since an inconstant correlation between body mass index (BMI) and these disturbances has been found (Kannel ,1985).

\section{Classification of Abdominal Fat}

As described by Märin et al., abdominal fat is composed of abdominal subcutaneous fat and intraabdominal fat, as clearly shown by CT and magnetic resonance imaging (MRI); intraabdominal adipose tissue is composed of visceral, or intraperitoneal, fat, mainly composed of omental and mesenteric fat and retroperitoneal fat masses by a delineation along the dorsal borderline of the intestines and the ventral surface of the kidney.

According to (Abate,et al,.1994) the two intraabdominal compartments are separated on 
MRI using anatomical points, such as ascending and descending colon, and aorta and inferior vena cava; such a procedure has been validated in human cadavers (Abate,et al..1994).

However, the lack of exact borderlines between these two depots on CT or MRI makes this subdivision only an approximation. Even a large error in the delineation between these two tissues would lead to the conclusion that, at least in men, the retroperitoneal fat mass is a minor part of intraabdominal adipose mass, comprising only approximately one fourth of visceral fat (Marin, et al,. 1992)

\section{Assessment of Abdominal Visceral Fat}

\section{A. Anthropometric indexes of abdominal} visceral adipose tissue mass

1. Waist Hip ratio (WHR). The WHR is the most widely used index of regional adipose tissue distribution and is measured in a standing position. Waist circumference is defined as the minimal circumference measured at the navel, and the hip circumference is defined as the widest circumference measured at the hips and buttocks (Kissebah,1997).

WHR predicted subsequent diabetes in men (Ohlson,et al,.1985) and coronary heart disease in both men and women (Larsson,et al 1984)(Lapidus,et al,.1984) and was more predictive of these endpoints than either the BMI or a more complex procedure using the sum of multiple skinfold thicknesses. Its effects are independent of the overall level of obesity.

2. Waist circumference. Of the body circumferences, the measurement at the abdomen or "waist" is the most variable in term of its location or position, especially among obese and elderly persons. For example, the waist circumference is correctly measured at the level of the umbilicus, but in many obese individuals, the umbilicus may be directed downward because of the excessive curvatures of the abdominal wall. Waist circumference measured at the midpoint between the lower border of the rib cage and the iliac crest has been reported to be more closely correlated with the level of abdominal visceral adipose tissue and associated metabolic variables than the WHR in both sexes (Pouliot,et al,.1994) (Ferland,1989)( Seidell ,et al,.1988)( DespreÁs,et al,. 1991). According to (Pouliot,et al,.1994), at least in French Canadians a waist circumference greater than $100 \mathrm{~cm}$ is most likely to be associated with disturbances in lipoprotein metabolism and in plasma glucose-insulin homeostasis .

On the other hand, while there was an association of visceral adiposity with insulin secretion during an oral glucose test in men, such was not found in women (Snehalatha,et al,.1997). In addition, it has been reported that visceral obesity is strongly related to coronary heart disease risk factors in nonobese Japanese-American men (Fujimoto,et al,.1994).

3. Abdominal sagittal diameter. Abdominal sagittal diameter is derived either from a CT abdominal scan (Pouliot,et al,.1994) or by using a carpenter's spirit level placed over the abdomen perpendicular to the length axis of the trunk at the iliac crest level when the subject is placed on a firm examination table. The sagittal diameter is measured with a ruler as the vertical distance from the horizontal spirit level to the examination table after a normal expiration (SjoÈstroł̀m,et al,.1996).

\section{B. Imaging techniques:}

1. Computed tomography (CT). CT can be considered the gold standard not only for adipose tissue evaluation but also for multicompartment body measurement (Chowdhury,et al,.1994), (SjoÈstroł̀m,et al,.1996). The reported error for the determination of total adipose tissue volume after performing 28 scans is $0.4 \%$, which supports the high reproducibility of CT. The subcompartments of adipose tissue volume, visceral and subcutaneous adipose tissue, can be accurately measured with errors of 1.2 and $0.5 \%$, respectively. Since the visceral fat volume has been determined from the visceral adipose tissue area of several scans, it is independent of individual visceral adipose tissue distributions; the precision error of this volume determination was reported to be in the order of $1 \%$ by (Chowdhury,et al,.1994). 
A

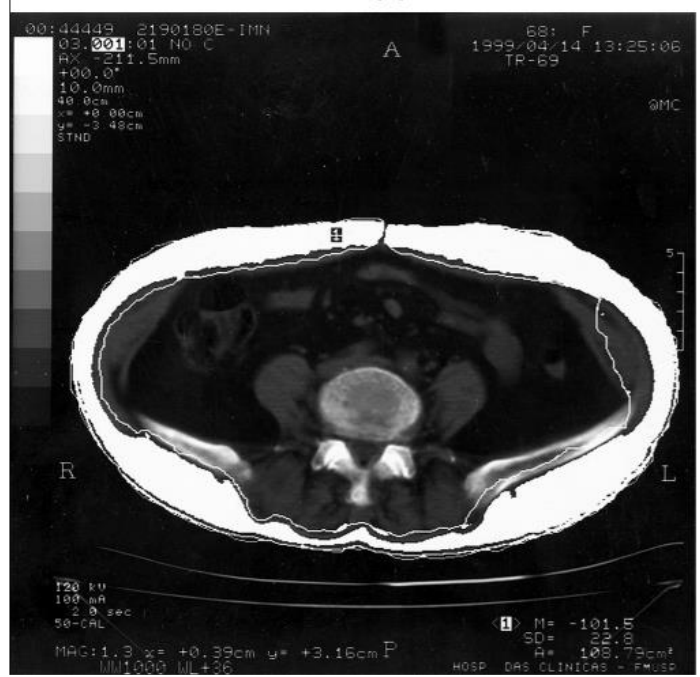

B

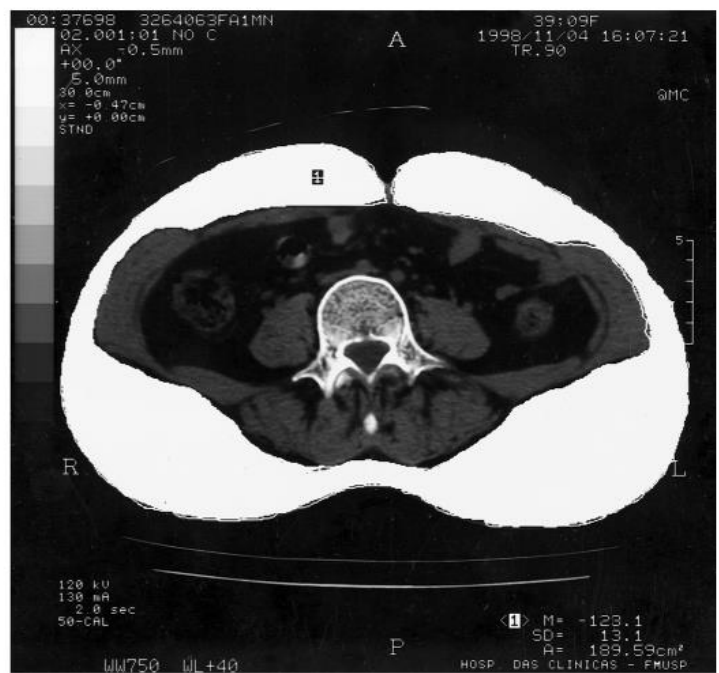

FIG. (1). Computed tomography showing cross-sectional abdominal areas at umbilicus level in two patients demonstrating variation in fat distribution. A, Visceral type (49-yr-old female, 23.1 of BMI, visceral fat area: $146 \mathrm{~cm}^{2}$; subcutaneous fat area, $115 \mathrm{~cm}^{2}$; V/S ratio, 1.27). B,

Subcutaneous type (40-yr-old female, 24.0 of BMI, visceral fat area: $60 \mathrm{~cm}^{2}$; subcutaneous fat area, $190 \mathrm{~cm}^{2} ; \mathrm{V} / \mathrm{S}$ ratio, 0.31).

\section{Magnetic resonance imaging (MRI). MRI} provided results similar to $\mathrm{CT}$ without exposure to ionizing radiation, the main problem with CT multislice measurements. It demonstrated good reproducibility for total and visceral adipose tissue volumes (Ross, et al,.1992), which were slightly lower than previously reported using CT (Kvist,et al,.1988), although the percent contribution of visceral to total adipose tissue volume was similar (18 vs. 20\%). Subcutaneous adipose tissue and visceral fat areas at the L4-L5 level determined in 27 healthy men by MRI were $252.8 \pm 132.9$ and $117.9 \pm 62.1 \mathrm{~cm} 2$ (mean \pm sd), respectively, and the differences between two measurements for a single scan ranged from 1.4 to $4.2 \%$ (Ross, et al,.1992).

These areas were highly predictive of the corresponding volume measurements computed from the 41-scan MRI, confirming the CT studies of (Kvist,et al,.1988), who made similar observations in both male and female subjects.

3. Ultrasound (US). US subcutaneous and intraabdominal thicknesses, the latter corresponding to the distance between abdominal muscle and aorta, were measured 5 $\mathrm{cm}$ from the umbilicus on the xipho-umbilical line with a $7.5-\mathrm{MHz}$ probe for subcutaneous adipose tissue and a $3.5-\mathrm{MHz}$ probe for intraabdominal fat (Zamboni,et al,.1996). The intraindividual reproducibility of US measurements was very high both for intraabdominal and subcutaneous thickness as well as for interoperators (Armellini,et al,.1993)( Tornaghi,et al,.1994).

Several studies demonstrated a highly significant correlation between the intraabdominal adipose tissue determined by CT and by US. A decade ago, (Armellini,et al,.1993)found a reasonable correlation ( $\mathrm{r}=$ 0.67) of intraabdominal US measurements with CT at the L4-L5 level. In a more recent study, ( Tornaghi,et al,.1994) found a highly significant correlation between intraabdominal thickness and CT visceral adipose tissue area ( $\mathrm{r}=0.89 \pm 0.91)$ and (Radominski,1998), at The Hospital das Clinicas of SaÄo Paulo, Brazil, also observed in 24 subjects an excellent correlation between ultrasonography and CT ( $\mathrm{r}=0.79$ for sc abdominal thickness and $\mathrm{r}=0.84$ for visceral adipose tissue), again indicating that US intraabdominal thickness is an excellent predictor of visceral abdominal adipose tissue (Armellini,et al,.1993) (Armellini,et al,.1991) (Armellini,et al,.1994). Furthermore, the cor-relation between abdominal sagittal diameter and $\mathrm{CT}$ in Radominski's study was lower than that observed between US and CT. In a crossvalidation study, intraabdominal ad-ipose tissue measured by CT was significantly correlated with intraabdominal adipose tissue 
predicted from an equa-tion using primarily US intraabdominal thickness ( $\mathrm{r} \quad 5 \quad 0.84)$ (Armellini,et al,.1994).

Eighty-seven patients (52 males and 35 females) were enrolled in a study done by (Hirooka, et al, .2005), both US and CT were performed, and the visceral fat volume was measured. Both the distance and thickness of the parameters in US were measured as follows:

1) The distance between the internal surface of the abdominal muscle and the splenic vein.

2) The distance between the internal surface of the abdominal muscle and the posterior wall of aorta on the umbilicus.

3) The thickness of the fat layer of the posterior right renal wall. Results The equation was calculated as follows: [visceral fat volume] $=-9.008+1.191 \times$ [distance between the internal surface of the abdominal muscle and the splenic vein $(\mathrm{mm})]+0.987 x$ [distance between the internal surface of the abdominal muscle and the posterior wall of the aorta on the umbilicus $(\mathrm{mm})]+3.644 \times[$ thickness of the fat layer of the posterior right renal wall $(\mathrm{mm})]$. There was a good correlation between the visceral fat volume calculated by the above equation and the volume by CT described $(\mathrm{r}=0.860$, $\mathrm{p}<0.0001$ ).this study delivered that the measurement of the visceral fat volume using US provided results as effectively as CT, and it was proven to be a useful method.

\section{IR and adipose tissue interrelationship:}

Recently, visceral adipose tissue has drawn attention as a source of several bioactive substances, known as adipocytokines, such as adiponectin, leptin, plasminogen activator inhibitor-1 and tumour necrosis factor-a, all of which are thought to contribute to IR. It is also well known that IR is strongly associated with the visceral adipose tissue area(Yoneda,et al,2007)

Frequent studies over the last decade showed that visceral adiposity is associated with and predicts the development of type 2 diabetes, coronary heart disease, and hypertension. The numerous studies emanating from the laboratories of Despre's and Bouchard (Pouliot,et al,.1992)( Lemieux,et al,.1996) since 1990 have reproducibly shown that visceral adiposity is the component of adiposity that is the independent risk factor for insulin resistance, glucose intolerance, and cardiovascular risk factors.

The aim of this study is to assess the validity of detection of visceral adipose tissue area with Ultrasonography and its correlation with insulin resistance in $\mathrm{HCV}$ patients

\section{Patients and methods:}

It is a prospective study for 1144 participants recruited through a cohort from a village in Monoufia governorate in Delta region of Egypt. The study protocol was approved by the Egyptian Ministry of Health and Population Institutional Review Board and a local ethics committee set up for hepatitis studies in Egypt.The study participants were subcategorized into two groups:

Group (I): included 867 healthy subjects (negative HCV RNA) as a control group.

Group (II): included 277 patients with chronic $\mathrm{HCV}$ as a study group.

Inclusion criteria were adult patients $>18$ years old,positive serology for $\mathrm{HCV}$ and $\mathrm{HCV}$ viremia,none diabetic (negative history and fasting blood sugar level $<126 \mathrm{mg} / \mathrm{dl}$ ) and none obese (BMI < 30).

Exclusion criteria were negative $\mathrm{HCV}$ viremia,positive $\mathrm{HBs} A g$,diabetic patients (known diabetic or FBS $>126 \mathrm{mg} / \mathrm{dl}$ ) and obese patients (BMI $>30)$.

All participating subjects, after a written consent, were subjected to the following Icareful history taking, Including age, present and past occupation and residence ,history of drug or alcohol intake, history of schistosomiasis and previous parenteral treatment for it , history of blood transfusion ,dental procedure and operations. Any associated disease as diabetes mellitus or hypertension and any present complaint IIThorough clinical examination.III. Anthropometric study was done for all studied patients focusing on evaluation of body mass index (BMI) which is equal to weight/height 2 (in $\mathrm{kg} / \mathrm{m} 2$ ); with BMI ranging between 19 to $25 \mathrm{~kg} / \mathrm{m} 2$ refer to normal average. BMI of 30 or more is most commonly used as threshold for obesity while BMI between 25 and 30 are suggesting overweight (CDC, 2009).IV. Laboratory assays including:

a) Glucose profile(Fasting glucose- Specific insulin assay- C-peptide-Adiponectin)

b) Liver function tests(AST,ALT,Bilirubin,Albumin,ALP,INR) 
c) Viral markers :hepatitis B surface antigen(HBs Ag), hepatitis $B$ core antibodies $(\mathrm{HBc} \mathrm{Ab})$ and hepatitis $\mathrm{C}$ virus antibodies(HCV Ab)

d)Qualitative HCV RNA by PCR.

\section{Laboratory assays:}

Blood sampling, about $10 \mathrm{ml}$ venous blood were obtained from each individual, $2 \mathrm{ml}$ were collected in a tube containing dipotassium EDETA as an anticoagulant for qualitative detection of HCV RNA , another $1.8 \mathrm{ml}$ were collected in a tube containing $0.2 \mathrm{ml}$ sodium citrate for PT detection. The remaining $6 \mathrm{ml}$ were collected in a plain tube, allowed to clot and centrifuged to get serum. Blood glucose and liver function tests were done immediately after centrifugation, the remaining serum was stored at $-20 \mathrm{oC}$ as aliquots for demonstration of insulin level, $\mathrm{C}$ peptide, and viral markers.

\section{The laboratory evaluations include:}

A-Glucose profile: fasting glucose level was measured by enzymatic colorimetric method using kit provided from Human, Germany. Insulin level and C-peptide were demonstrated in serum by using semi-automated ELISA system (TC,96, USA), kit provided from DRG International,USA.The absorbance values were read using ELISA reader at wave length $450+10 \mathrm{~nm}$ for both insulin and Cpeptide(Chieregatti,1999).

The concentrations were calculated using computer software capable of generating a four parameters algorithm.

*Calculation of insulin resistance according to HOMA score (homeostasis model assessment), (Matthews et al., 1985).using the following:

HOMA insulin resistance score $=$

Fasting glucose $(\mathrm{mmol} / \mathrm{l} \mathrm{x}$ insulin $(\mathrm{Uu} / \mathrm{ml})$

$$
22.5
$$

B-Liver function tests and lipid profile were measured by semi automated chemical analyzer (Chem 7 plus,Germany), using kit provided from ELI Tech, France,for AST,ALT and ALP and from Human, Germany for albumin, bilirubin, PT and serum lipid.

\section{C-Viral laboratory assessment:}

1.Serological tests for $\mathrm{HBsAg}, \mathrm{HBcAb}$ and $\mathrm{HCVAb}$ by ELISA technique(Chieregatti,1999), using kit provided from EIA gen, Adaltis, Italy. The color intensity was measured at $450 \mathrm{~nm}$ with reference filter 620- $630 \mathrm{~nm}$. The concentrations have been calculated automatically using 4 parameter logistics computer software.

2. Qualitative detection of HCV RNA by the method of Reverse Transcriptase PCR, this falls into four main steps:

*HCV RNA extraction using the QIAmp Viral RNA kit, Germany, then this is followed by cDNA synthesis within 3 hours or stored at -80 OC for up to one month with no more than one freeze-thraw.

*Reverse transcription of extracted HCV RNA into complementary DNA(c- DNA) and first round PCR amplification using primers for $\mathrm{HCV}$, the sequences of the primers were as follows:

P1 5'AACTACTGTCTTCACGCAGAA3' P2 5'GGTGCACGGTCTACGACCTC3'.

The amplification procedure was performed by thermal cycler apparatus (PTC-200, USA) programmed as follows; $42^{\circ} \mathrm{C}$ for $30 \mathrm{~min}$; $95^{\circ} \mathrm{C}$ for $5 \mathrm{~min}$ followed by 30 cycles $\left(94^{\circ} \mathrm{C}\right.$ for $1 \mathrm{~min}, 55^{\circ} \mathrm{C}$ for $1 \mathrm{~min}$ and $72^{\circ} \mathrm{C}$ for 1 minute) and finally $72^{\circ} \mathrm{C}$ for $5 \mathrm{~min}$.

*Second round PCR amplification was performed in a thermocycler programmed as follows; $95^{\circ} \mathrm{C}$ for $5 \mathrm{~min}$ followed by 30 cycles $\left(94^{\circ} \mathrm{C}\right.$ for $1 \mathrm{~min}, 55^{\circ} \mathrm{C}$ for $1 \mathrm{~min}$ and $72^{\circ} \mathrm{C}$ for 1 minute) and finally $72^{\circ} \mathrm{C}$ for $5 \mathrm{~min}$, using primers with sequences as follows:

P3 5'GTGCAGCCTCCAGGACCC3'

P4 5'ACTCGGCTAGCAGTCTCGCG3'.

*Detection of the amplified fragments by loading the amplified products on $2.5 \%$ agarose gel and visualized using UV transilluminator. Band sizes were compared to a 50-bp DNA ladder. A fragment of $171 \mathrm{bp}$ length was identified as a positive sample.

\section{ADIPONECTIN:}

\section{SAMPLE COLLECTION AND STORAGE- TECHNIQUE:}

Ten ml of venous blood were withdrawn from patients; allow blood samples to clot for 30 min before centrifugation for $15 \mathrm{~min}$. Aliquoted serum into 3 aliquots and store samples at $-80^{\circ} \mathrm{C}$.

Normal Level: 20.5 - $157 \mathrm{ng} / \mathrm{mL}$ (Scherer, et al,1995). 


\section{C-PEPTIDET:}

\section{SAMPLE COLLECTION AND STORAGE- TECHNIQUE:}

Ten $\mathrm{ml}$ of venous blood were withdrawn from patients; allow blood samples to clot for 30 min before centrifugation for $15 \mathrm{~min}$. Aliquoted serum into 3 aliquots and store samples at $-80^{\circ} \mathrm{C}$.

Normal Level:0.72 - $9.12 \mathrm{ng} / \mathrm{mL}$ (Ashby and

Frier,1981)

V. Ultrasound measurements:

- Abdominal ultrasound was performed to assess regional fat distribution; a special sheet format was used to record data.

\section{Patient preparation:}

1. Patient was fasting while he was in the village for at least 8 hours.

2. It was preferred to give the patients antiflatulence drugs in the day preceding the day of examination.

\section{Type of the scanner:}

3. The examination was done by Siemens machine equipped with $3.5-5 \mathrm{MHz}$ curved transducer, however 7 or $12 \mathrm{MHz}$ linear transducer was used also.

4. The coupling agent (aquasonic gel) was spread as a film on the abdomen to prevent interposition of air between the transducer and the skin.

\section{Ultrasound examination:}

5. Abdominal examination was done in supine, right and left lateral positions. Scanning was done in through several longitudinal, transverse and oblique cuts and measurements were done in quiet respiration.
2. Estimation for the abdominal fat was done according to the following methodology:

- All ultrasound measurements were made at the expiratory phase of quiet respiration. Application of the transducer on the body surface was done without undue pressure that would alter the body layer contour and thickness.

- Measurement of subcutaneous fat with 7-12 $\mathrm{MHz}$ linear transducer transversely placed perpendicular to the skin in the midline of abdomen, between the xiphoid process and umbilicus. The maximum thickness of subcutaneous fat was measured three times and the mean value was taken.

- Measurement of Mesenteric fat by 3-5 MHz curved transducer through identifying mesenteric leaves in para umbilical area, which appeared as elongated structures with highly reflecting peritoneal surfaces. It had high-level echoes in the periphery and small vascular structures (1-2mm in diameter) could be seen within it. Specular echoes corresponding to their peritoneal surfaces divided the mesenteric leaves from each other. The mesenteries demonstrated no peristalsis, in contrast to small bowel loops attached to the distal end when different mesenteric leaves were visualized, the maximum thickness was measured. Usually 6-10 measurements were made on each ultrasound examination, and the mean of the three thickest mesenteric leaves was used for the analysis.

- Preperitoneal fat thickness was measured with modified criteria of Suzuki et al. It was scanned longitudinally with $\mathrm{L} 7-12 \mathrm{MHz}$ linear transducer placed perpendicular to the skin surface and scanned along the midline of the abdomen, between xiphoid process and umbilicus. The maximum thickness of preperitoneal fat was measured three times and the mean value was taken for analysis. 
Figure (2): Abdominal subcutaneous fat

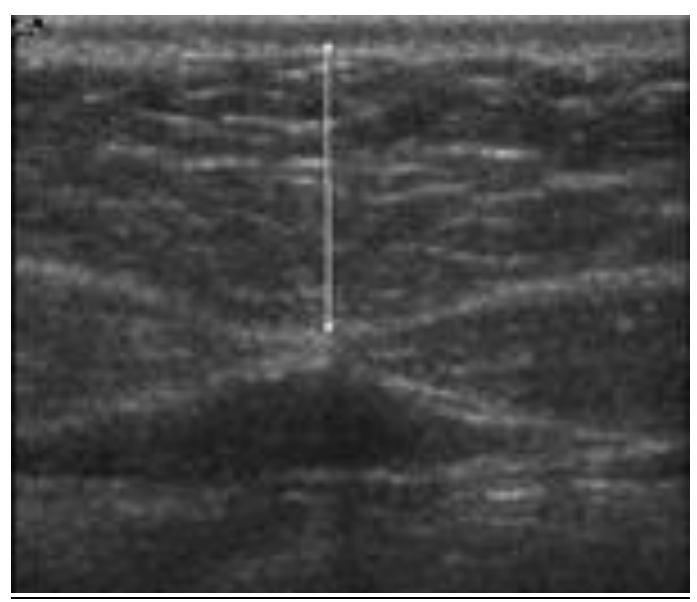

Figure (3): Abdominal preperitoneal fat

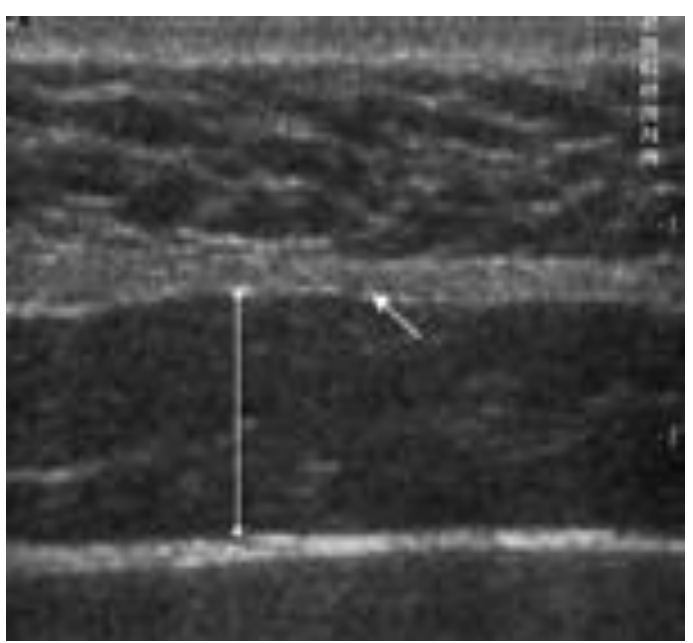

Figure (4): Abdominal mesentric fat

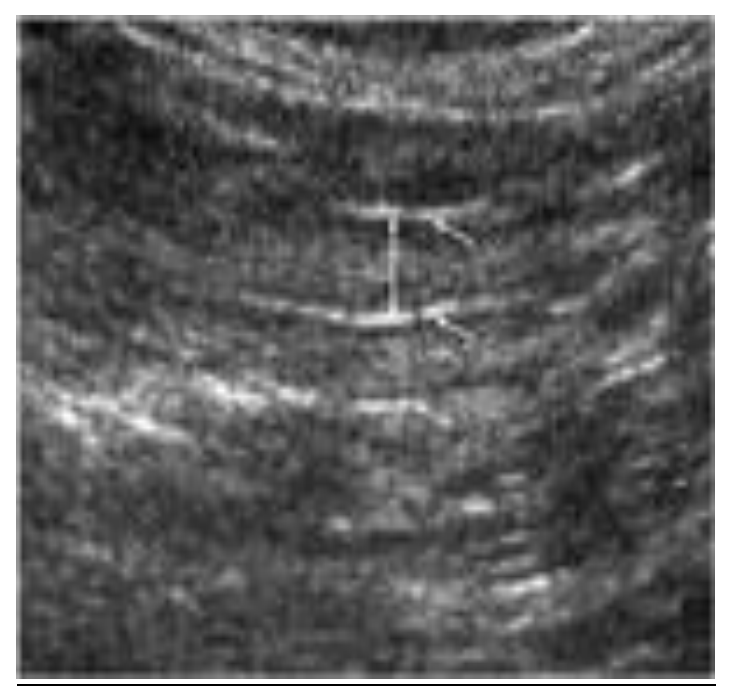


Saving the Data:

Images were saved as Dicome formate through either MOD or by direct cable.

Statistical analysis:

We used following software in our research statistics SPSS version 16 and Microsoft excel with analyze-it add in.Description of qualitative variables by frequency and percentage.description of quantitative variables in the form of mean and standard deviation (mean $\pm \mathrm{SD}$ ). Chi-square (x2) test was used for comparison of qualitative variables with each other.Comparison between quantitative variables was carried by using student t-test of two independent samples. One way ANOVA test (analysis of variance) was used instead of t-test for comparison of more than two quantitative groups.Kruskal wallis ANOVA test used for categorical data.Significance level (p) was expressed as following: $\mathrm{P}$ value $>0.05$ is insignificant, $\mathrm{P}$ value $<0.05$ is significant and $P$ value $<0.001$ is highly significant.Correlation studies were done using person test for quantitative data and spearman test for categorical data.

\section{Results:}

Table (1) physical parameters of the studied groups.

\begin{tabular}{|l|c|c|c|c|l|}
\hline & \multicolumn{2}{|c|}{ Group I } & \multicolumn{2}{c|}{ Group II } & \\
\hline & Mean & SD & Mean & SD & P Value \\
\hline Weight $($ Kg) & $\mathbf{6 5 . 9 6}$ & $\mathbf{1 0 . 4 0}$ & $\mathbf{6 6 . 9 1}$ & $\mathbf{1 0 . 0 8}$ & $>\mathbf{0 . 0 5}$ \\
\hline Height $(\mathbf{c m})$ & $\mathbf{1 6 2 . 1 9}$ & $\mathbf{8 . 8 8}$ & $\mathbf{1 6 4 . 3 5}$ & $\mathbf{8 . 7 5}$ & $<\mathbf{0 . 0 5}(\mathbf{S})$ \\
\hline BMI & $\mathbf{2 5 . 0 2}$ & $\mathbf{2 . 9 7}$ & $\mathbf{2 4 . 7 6}$ & $\mathbf{2 . 8 5}$ & $>\mathbf{0 . 0 5}$ \\
\hline waist(cm) & $\mathbf{7 9 . 7 6}$ & $\mathbf{9 . 9 1}$ & $\mathbf{8 0 . 5 2}$ & $\mathbf{9 . 8 7}$ & $>\mathbf{0 . 0 5}$ \\
\hline
\end{tabular}

Table (1) shows no significant difference was found between both groups as regarding weight, waist circumference and BMI.

Table (2): Lipid profile in the studied groups.

\begin{tabular}{|c|c|c|c|c|c|c|}
\hline & & \multicolumn{2}{|c|}{ Group I } & \multicolumn{2}{|c|}{ Group II } & P Value \\
\hline $\begin{array}{l}\text { CHOL (100- } \\
\text { 200mg/dl) }\end{array}$ & Mean +S.D. & 185.71 & 49.24 & 164.18 & 41.87 & $<0.05(\mathrm{~S})$ \\
\hline TG (35-160mg/dl) & Mean +S.D. & 96.27 & 65.03 & 87.30 & 42.57 & $<0.05(\mathrm{~S})$ \\
\hline HDL (29-85 mg/dl) & Mean +S.D. & 47.50 & 20.67 & 46.59 & 16.40 & $>0.05$ \\
\hline
\end{tabular}

Table (2) describe the lipid profile of the studied groups, cholesterol and triglycerides are significantly higher in the control group while no significant difference regarding HDL level.

Table (3): Glucose profile of the studied groups.

\begin{tabular}{|l|c|c|c|c|c|}
\hline & \multicolumn{2}{|c|}{ Group I } & \multicolumn{2}{c|}{ Group II } & \\
\hline & Mean & SD & Mean & SD & P Value \\
\hline F.B.S(mg/dI) & $\mathbf{8 0 . 6 3}$ & $\mathbf{9 . 3 6}$ & $\mathbf{8 1 . 6 2}$ & $\mathbf{9 . 2 6}$ & $>\mathbf{0 . 0 5}$ \\
\hline Insulin $(\boldsymbol{\mu}$ U/ml) & $\mathbf{3 . 8 7}$ & $\mathbf{2 . 7 0}$ & $\mathbf{4 . 9 1}$ & $\mathbf{3 . 8 2}$ & $<\mathbf{0 . 0 5 ( S )}$ \\
\hline HOMA & $\mathbf{0 . 8 3}$ & $\mathbf{0 . 6 0}$ & 1.09 & $\mathbf{0 . 9 3}$ & $<\mathbf{0 . 0 5 ( S )}$ \\
\hline $\begin{array}{l}\text { C-Peptide(0.6-13.06 } \\
\text { ng/ml) }\end{array}$ & 1.29 & 1.28 & 1.18 & 1.20 & $>\mathbf{0 . 0 5}$ \\
\hline
\end{tabular}

As shown in table (3).Comparing HOMA-Score in both groups, the test was significantly higher in the study group than the control group, also serum insulin level being one of the HOMA equation components is significantly higher in the study group than in control group, meanwhile, the fasting blood sugar and c-peptide show no significant difference between both groups. 
Table (4): markers related to visceral adiposity (adiponectin) in studied groups.

\begin{tabular}{|c|c|c|c|c|c|}
\hline & \multicolumn{2}{|c|}{ Group I } & \multicolumn{2}{c|}{ Group II } & \\
\hline & Mean & SD & Mean & SD & P Value \\
\hline $\begin{array}{c}\text { Adiponectin (19.8-143 } \\
\text { ng/ml) }\end{array}$ & 48.00 & 42.07 & 73.27 & $\mathbf{6 3 . 9 9}$ & $>\mathbf{0 . 0 5}$ \\
\hline
\end{tabular}

Table (4) show no significant difference between both groups as regarding adiponectin level.

Table (5): abdominal fat measurements by U/S.

\begin{tabular}{|l|c|c|c|c|c|c|}
\hline & & \multicolumn{2}{|c|}{ Group I } & \multicolumn{2}{c|}{ Group II } & P Value \\
\hline $\begin{array}{l}\text { Subcutaneous Fat } \\
\text { Thickness(mm) }\end{array}$ & Mean +S.D. & 10.51 & 3.68 & 9.49 & 3.37 & $<0.05(\mathrm{~S})$ \\
\hline $\begin{array}{l}\text { Mesenteric Fat } \\
\text { Thickness (mm) }\end{array}$ & Mean +S.D. & 32.03 & 11.72 & 34.22 & 11.46 & $>0.05$ \\
\hline $\begin{array}{l}\text { Preperitoneal Fat } \\
\text { Thickness (mm) }\end{array}$ & Mean +S.D. & 16.05 & 7.40 & 16.81 & 7.51 & $>0.05$ \\
\hline
\end{tabular}

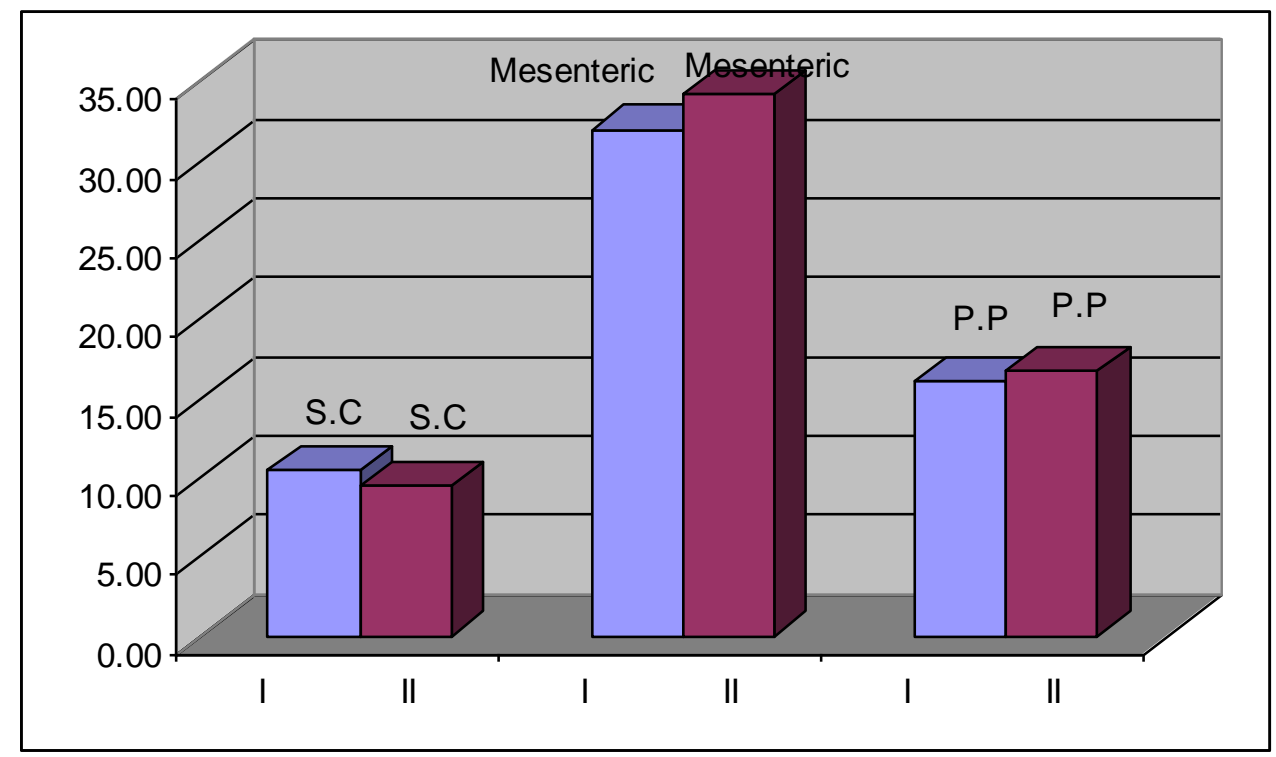

Fig (5): sonographic measurements of abdominal fat in the studied groups.

As reported in table (5), Fig (5), the studied groups show significant difference in measurements of subcutaneous fat thickness being higher in the control group than the study group , on the other hand no significant difference was observed between both groups regarding visceral fat thickness or preperitoneal fat thickness . 
Detection of...

Table (6): Nonparametric correlations (spearman correlation) between HOMA and other parameters:

\begin{tabular}{|c|c|c|}
\hline \multirow{3}{*}{ HOMA } & & \\
\hline \multirow{4}{*}{} & & CHOL \\
\cline { 2 - 3 } & Correlation Coefficient & -.074 \\
Sig. (2-tailed) & .288 \\
\cline { 2 - 3 } & & TG \\
\cline { 2 - 3 } & Correlation Coefficient & $.151^{*}$ \\
Sig. (2-tailed) & .030 \\
\cline { 2 - 3 } & & HDLC \\
\cline { 2 - 3 } & Correlation Coefficient & -.054 \\
Sig. (2-tailed) & .460 \\
\cline { 2 - 3 } & & C-Peptide \\
\cline { 2 - 3 } & Correlation Coefficient & .002 \\
Sig. (2-tailed) & .981 \\
\hline
\end{tabular}

\begin{tabular}{|c|c|c|}
\hline $\begin{array}{c}\text { HOMA } \\
\text { Continue }\end{array}$ & & Adiponectin \\
\hline \multirow{5}{*}{} & Correlation Coefficient & -.201 \\
Sig. (2-tailed) & .162 \\
\cline { 2 - 3 } & & Subcutaneous Fat \\
Thickness
\end{tabular}

**. Correlation is highly significant at the 0.01 level (2-tailed).

*. Correlation is significant at the 0.05 level (2-tailed). 

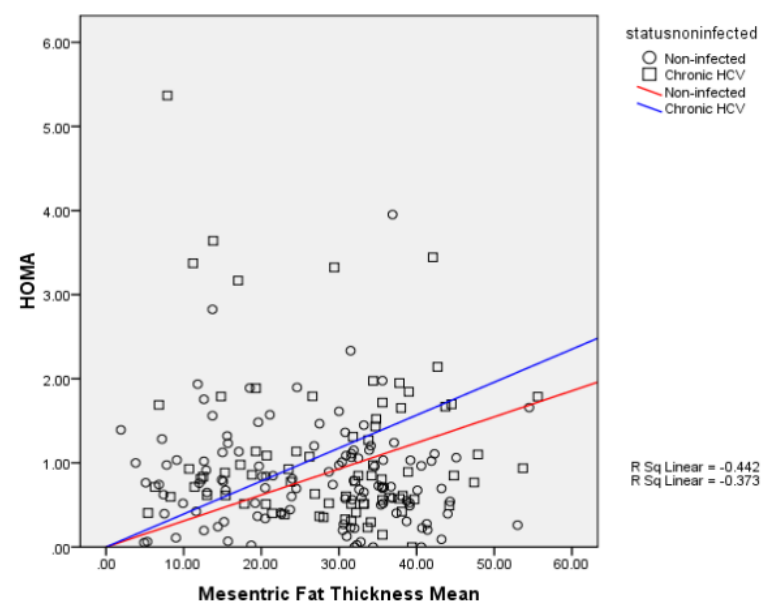

Fig (6): Correlation between HOMA and mesenteric fat thickness.

Table(6) Fig(6) shows nonparametric correlations (spearman correlation) between HOMA index and cholesterol, triglycerides, HDL, C- peptide, adiponectin BMI,subcutaneous ,mesenteric and preperitoneal fat thicknesses and we observe high significant correlation between HOMA index and subcutaneous fat thickness, mesenteric fat thickness(visceral adiposity) and BMI , and significant correlation between HOMA Index and triglycerides. These correlations were emphasized through the scattered plot curves between HOMA versus visceral adiposity.

Table (7): Nonparametric correlations (spearman correlation) between visceral adiposity and other parameters:

\begin{tabular}{|c|c|c|}
\hline & & GLU \\
\hline \multirow[t]{13}{*}{$\begin{array}{c}\text { Mesentric Fat } \\
\text { Thickness Mean } \\
\text { Continue }\end{array}$} & $\begin{array}{l}\text { Correlation Coefficient } \\
\text { Sig. (2-tailed) }\end{array}$ & $\begin{array}{l}.027 \\
.577\end{array}$ \\
\hline & & HOMA \\
\hline & $\begin{array}{l}\text { Correlation Coefficient } \\
\text { Sig. (2-tailed) }\end{array}$ & $\begin{array}{c}.341 * * \\
.001\end{array}$ \\
\hline & & C-Peptide \\
\hline & $\begin{array}{l}\text { Correlation Coefficient } \\
\text { Sig. (2-tailed) } \\
\end{array}$ & $\begin{array}{l}.054 \\
.296 \\
\end{array}$ \\
\hline & & Adiponectin \\
\hline & $\begin{array}{l}\text { Correlation Coefficient } \\
\text { Sig. (2-tailed) } \\
\end{array}$ & $\begin{array}{l}-.222 \\
.129 \\
\end{array}$ \\
\hline & & $\begin{array}{c}\text { Subcutaneous Fat } \\
\text { Thickness } \\
\end{array}$ \\
\hline & $\begin{array}{c}\text { Correlation Coefficient } \\
\text { Sig. (2-tailed) } \\
\end{array}$ & $\begin{array}{c}.168^{* * *} \\
.001 \\
\end{array}$ \\
\hline & & $\begin{array}{c}\text { Preperitoneal Fat } \\
\text { Thickness } \\
\end{array}$ \\
\hline & $\begin{array}{c}\text { Correlation Coefficient } \\
\text { Sig. (2-tailed) }\end{array}$ & $\begin{array}{l}.108^{*} \\
.026\end{array}$ \\
\hline & & BMI \\
\hline & $\begin{array}{c}\text { Correlation Coefficient } \\
\text { Sig. (2-tailed) }\end{array}$ & $\begin{array}{l}.142^{* *} \\
.003 \\
\end{array}$ \\
\hline
\end{tabular}

**. Correlation is highly significant at the 0.01 level (2-tailed).

*. Correlation is significant at the 0.05 level (2-tailed). 
Table (7) shows nonparametric correlations (spearman correlation) between visceral adiposity and,HOMA ,glucose ,insulin ,C-peptide,adiponectin,BMI, subcutaneous, and preperitoneal fat thicknesses and we observe high significant correlation between visceral adiposity and HOMA index,subcutaneous fat thickness and BMI, and significant correlation between visceral adiposity and preperitoneal fat thickness.

\section{Discussion:}

Our study was conducted on 277 patients with $\mathrm{HCV}$ and 867 healthy controls. We studied the validity of detection of visceral adipose tissue area with ultrasonography and its correlation with insulin resistance.

BMI was correlated with the degree of IR in $\mathrm{HCV}$ patients and also the degree of insulin resistance (Kahn and Flier, 2000) (Petersen et al., 2003).

This agrees with our study results as we found high significant correlation between insulin resistance as estimated by HOMA \& the BMI $(p<0.0001)$.

Insulin resistance evaluated by HOMA-IR and QUICKI was correlated with visceral fat accumulation in HCV patients (Eguchi et al., 2009).this findings are in the agreement results with our study as we found significant correlation between IR and visceral adiposity $(\boldsymbol{P}<0.001)$.

(Eguchi et al., 2009) declared that HCVinfected patients with visceral obesity showed significantly higher IR than in NAFLD patients with visceral obesity. These results indicate that IR in $\mathrm{HCV}$-infected patients with visceral obesity develops in the skeletal muscle as well as in the liver. David et al, (2000) mentioned that visceral adipose tissue had a strong (negative) correlation with IR as measured by the euglycemic insulin infusion method. Moreover, visceral adipose tissue was associated with blood pressure, fasting insulin, and lipids in a pattern entirely consistent with numerous previous reports indicating the correlation of visceral adiposity with the IR syndrome.

In contrast, (Yoneda et al., 2007) disagreed with this hypothesis and stated that HCV directly associates with IR independent of the visceral fat area.

Infection with hepatitis $\mathrm{C}$ virus (HCV) has been associated with alterations in lipid metabolism in some studies and type 2 diabetes in others (Marzouk et al, 2007). (Dai et al, 2008) found that the serum cholesterol and triglyceride levels in hepatitis $\mathrm{C}$ patients were significantly lower than in those subjects who were HCV RNA negative.

These findings matched with the current study results which revealed that total cholesterol, triglycerides are significantly lower in the infected group.

Elucidation of the U/s role in detection and measurement of abdominal fat has been recognized by Hirooka et al.(2005) who stated that the measurement of visceral fat volume using US provided results as effectively as CT, and it was proven to be a useful method.

This is in agreement with our results of the current study. Many studies utilized other imaging modalities in detection of various types of abdominal fat like CT and MRI, but through this study we try to validate the use of abdominal ultrasonography as a simple, cheap and easy method comparable to other radiological modalities in measurements of abdominal obesity, we didn't only find relation between IR and visceral adiposity but also there was significant correlation between IR and subcutaneous fat area $(P<0.001)$.

As noticed from our study, the relation between IR and visceral adiposity seems to be clearer whenever was high values of visceral fat thickness.

\section{Summary}

Ultrasonography is a simple, non-invasive, safe method in detection of visceral adiposity, which is correlated significantly with IR in chronic HCV patients.

\section{Conclusion}

- Ultrasonography is a simple, noninvasive, safe method in detection of visceral adiposity.

- Visceral adiposity is correlated significantly with IR in chronic HCV patients.

\section{Recommendations \\ Validation of ultrasonographic detection of visceral adiposity as a reflection of IR in chronic HCV}


patients and its correlation with disease morbidity is recommended.

\section{References:}

\begin{abstract}
Abate N, Burns D, Peshock RM, Garg A, Grundy $S M$ (1994): Estimation of adipose tissue mass by magnetic resonance imaging: validation against dissection in human cadavers. J Lipid Res 1994;35: 1490-1496
\end{abstract}

Armellini F, Zamboni $M$, Rigo L, BergamoAndreis IA, Robbi R, De Marchi M, Bosello $O$ (1991):Sonography detection of small intraabdominal fat variations. Int $\mathbf{J}$ Obes 1991;15:847-852.

Armellini F, Zamboni M, Robbi R, Todesco T, Rigo L, Bergamo-Andreis IA, Bosello $O($ 1993):Total and intra-abdominal fat measurements by ultrasound and computerized tomography. Int $\mathbf{J}$ Obes 1993;17:209-214.

Armellini F, Zamboni M, Castelli S, Micciolo $R$, Mino A, Turcato E, Rigo L, Bergamo-Andreis IA, Bosello $O$ (1994): Measured and predicted total and visceral adipose tissue in women. Correlations with metabolic parameters. Int $\mathbf{J}$ Obes Relat Metab Disord 1994;18:641-647.

Ashby,J.and Frier ,B.(1981):Circulating Cpeptide, measurements and clinical applications. Annals of clinical biochemistry1981;18:125.

Chowdhury B, Sjo“ stro "m L, Alpsten M, Kostanty J, Kvist H,Löfgren R (1994): A multicompartment body composition technique based on computorized tomography. Int J Obes Relat Metab Disord 1994;18:219-234.

CDC (2005):Overweight and obesity web page, defining overweight and obesity, May 28, 2005.

Despre`s J-P, Prud'homme D, Pouliot MC, Tremblay A, Bouchard C (1991): Estimation of deep abdominal adipose tissue accumulation from simple anthropometric measurements in men.AmJ Clin Nutr 1991;54:471-477.

David E. Kelley, F. Leland Thaete, Fred Troost, Trina Huwe and Bret $H$. Goodpaster (2000):Subdivisions of subcutaneous abdominal adipose tissue and insulin resistance. Am J Physiol Endocrinol Metab 2000;278:941-948.

D Marzouk, J Sass, I Bakr, M El Hosseiny, M Abdel-Hamid, C Rekacewicz, N Chaturvedi, M K Mohamed, A Fontanet(2007): Metabolic and cardiovascular risk profiles and hepatitis $\mathrm{C}$ virus infection in rural Egypt, Gut 2007;56;1105-1110

Dai C, Chuang W, Ho C, et al (2008): Associations between hepatitis $C$ viremia and low serum triglyceride and cholesterol levels: A community-based study Journal of Hepatology 49 (2008) 9-16.
Eguchi Y, Mizuta T, Ishibashi E, et al. (2009):Hepatitis $C$ virus infection enhances insulin resistance induced by visceral fat accumulation.Liver Int. 2009 ;29(2):213-20.

Feinleib M (1985):Epidemiology of obesity in relation to health hazards. Ann Intern Med 1985;103:1019-1024.

Ferland M, Despre`s J-P, Tremblay A, Pinault $S$, Nadeau A, Moorjani S, Lupien PJ, The'riault G, Bouchard C (1989):Assessment of adipose tissue distribution by computed axial tomography in obesewomen: association with body density and anthropometric measurements. Br J Nutr 1989;61:139-148.

Fujimoto WY, Abbate SL, Kahn SE, Hokanson JE, Brunzell JD( 1994): The visceral adiposity syndrome in Japanese-American men.Obesity Res 1994; 2:364-371.

Kannel WB (1985):Lipids, diabetes and coronary heart disease: insights from the Framingham Study. Am Heart J 1958;110:1100-1107.

Kissebah AH( 1997):Central obesity: measurement and metabolic effects. Diabetes Rev 1997; 5:8-20.

Kvist H, Chowdhury B, Grangard U, Tyle'n U, Sjo“ stro"m L (1988): Total and visceral adiposetissue volumes derived from measurements with computed tomography in adult men and women: predictive equations. Am J Clin Nutr 1988;48:1351-1361.

Kahn BB, Flier JS(2000):.Obesity and insulin resistance. J Clin Invest 2000;4:473-81.

Lapidus L, Bengtsson C, Larsson B, Pennert K, Rybo E, Sjo " stro $m L$ (1984):Distribution of adipose tissue and risk of cardiovascular disease and death: a 12 year follow-up of participants in the population study of women in Gothenburg, Sweden. Br Med J (Clin Res Ed) 1984;289:12571261.

Larsson B, Svärdsudd K, Welin L, Wilhelmsen L, Bjo rntorp P,TibblinG (1984):Abdominal adipose tissue distribution, obesity and risk of cardiovascular disease and death: 13 year follow-up of participants in the study of men born in 1913. Br Med J (Clin Res Ed) 1984;288:1401-1404.

Lemieux S, Tremblay A, Prud-Homme D,Bouchard C, Nadeau A, Despre's J$P(1996)$ : Seven-year changes in body fat and visceral adipose tissue in women: associations with indexes of plasma glucose-insulin homeostasis. Diabetes Care 1996;19:983-991

Märin P, Andersson B, Ottosson M, Olbe L, Chowdhury B, Kvist H, Holm G, Sjo " stro"m L, Björntorp $P$ (1992): The morphology and metabolism of intraabdominal adipose tissue in men. Metabolism 1992;41:1242-1248

M. Yoneda, S. Saito, T. Ikeda, K. Fujita, H. Mawatari, et al.(2007):Hepatitis C virus directly associates with insulin resistance independent of 
the visceral fat area in nonobese and nondiabetic patients, Journal of Viral Hepatitis, 2007; 14, 600607.

Masashi Hirooka, Teru KUMAGI, Kiyotaka KUROSE, et al. (2005): A Technique for the Measurement of Visceral Fat by Ultrasonography: Comparison of Measurements by Ultrasonography and Computed Tomography, Internal Medicine 2005;44, 8:794-795.

Ohlson LO, Larsson B, Svärdsudd K, Welin L, Eriksson H, Wilhelmsen L, Björntorp P, Tibblin $G$ (1985): The influence of body fat distribution on the incidence of diabetes mellitus-13.5 years of follow-up of the participants in the study of men born in 1913.Diabetes 1985; 34:1055-1058.

Pouliot MC, Despre`s J-P, Lemieux S, Moorjani $S$, Bouchard C,Tremblay A, Nadeau A, Lupien PJ (1994): Waist circumference and abdominal sagittal diameter: best simple anthropometric indexes of abdominal visceral adipose tissue accumulation and related cardiovascular risk in men and women. Am J Cardiol 1994;73:460-468.

Pouliot MC, Despre's J-P, Nadeau A, Moorjani S, Prud'Homme D, Lupien PJ,Tremblay A, Bouchard C(1992): Visceral obesity in men: associations with glucose tolerance,plasma insulin, and lipoprotein levels.Diabetes 1992;41:826-834.

Petersen KF, Befroy D, Dufour S, et al.(2003): Mitochondrial dysfunction in the ederly: possible role in insulin resistance. Science 2003; 300:1140-2.

Ross R, Leger L, Morris D, de Guise J, Guardo R( 1992):Quantification of adipose tissue by MRI: relationship with anthropometric variables. J Appl Physiol 1992; 72:787-795.
Seidell JC, Oosterlee A, Deurenberg P, Hautavast JG, Ruijs JH (1988):Abdominal fat depots measured by computed tomography: effects of degree of obesity, sex, and age. Eur J Clin Nutr 1988;42:805-815.

Snehalatha C, Ramachandran A, Satyavani K, Vallabi MY,Viswanathan V( 1997):Computed axial tomography scan measurement of abdominal fat distribution and its correlation with anthropometry and insulin secretion in health Asian Indians. Metabolism 1997; 46:1220-1224.

Sjo“ stro $m L$, Lo"nn L, Chowdhury B, Grangärd Lissner L, Sjo“strom D, Sullivan L (1996 ): The sagittal diameter is a valid marker of the visceral adipose tissue volume. In: Progress in Obesity Research: Proceedings of the Seventh International Congress on Obesity (Toronto, Canada, August 2025, 1996). John Libbey \& Company,London,1996; 7:309-319.

Tornaghi G, Raiteri R, Pozzato C, Rispoli A, Bramani $M$, Cipolat $M$, Craveri $A$ (1994):Anthropometric or ultrasonic measurements in assessment of visceral fat? A comparative study. Int J Obes 1994;18:771-775.

Zamboni M, Armellini F, Muller D, Sorkin J, Turcato $E, \quad$ Andres $R$, Bosello $O$ (1996): Methodological and clinical aspects of subcutaneous fat distribution. In: Angel A, Anderson H, Bouchard C, Lau D, Leiter L, Mendelson R (eds) Progress in Obesity Research: Proceedings of the Seventh International Congress on Obesity (Toronto, Canada, August 20-25, 1994) John Libbey \& Company,London, 1996; 7:145150. 


\section{تقبيم استخدام الفحص بالموجات فوق الصوتية لتحديا سعك النسيج الدهني حول الأحشاء

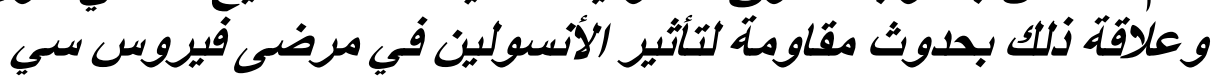 \\ مصطفى كمال محمد(1),جمال عصمت(2), محمد سعيد عبدالعزيز (2), محمد عبدالحميد(3), محمد حساني(4), محمد

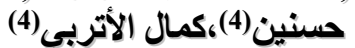

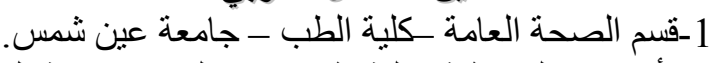

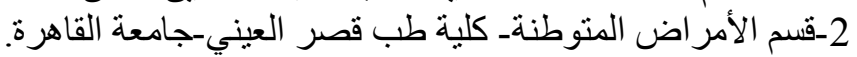

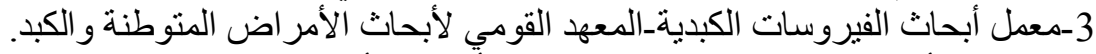 \\ 4-قسم الأمر اض المنوطنةـ المعهد القومي لأبحاث الأمر اض الأن المنوطنة والكبد.}

تعتبر الأصسابة بفيروس سي الكبدي سببا أساسياً لأمر اض الكبد المزمنة ويمثل مشكلة صحية قومية في

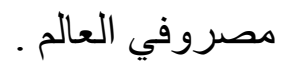

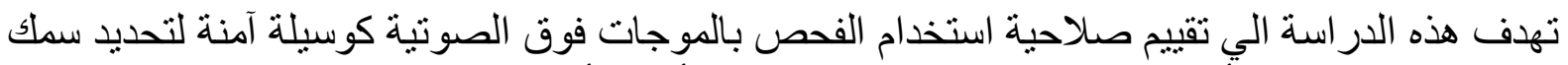

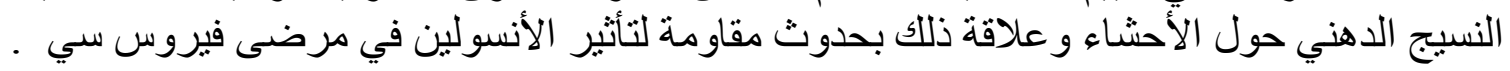

اشتملت الدر اسة على 1144 شخص تم تقسيمهم كالآتي : 867 شخص سليم (المجمو عه الضابطه) غير مصاب بفيروس سي و 277 مريض مصاب بفيروس الألتهاب الكبدي سي.

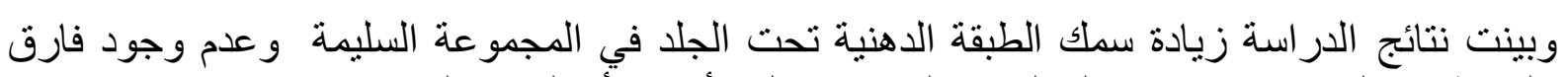
ملحوظ بين المجموعتين في سمك النسيح الدهني حول الطيقة الأحشاء أَّ النسيج البريتوني.

و أظهرث الدراسة وجود علاقة طردية ذات دلالة بين حدوث مقاومة للأنسولين وبين الدهون الثنلاثية

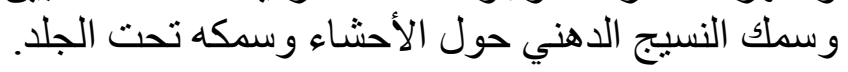

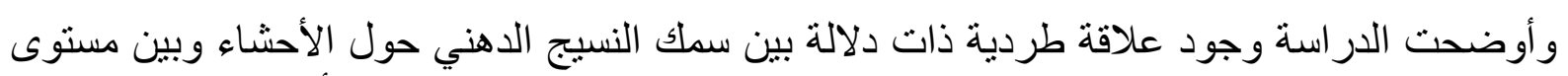

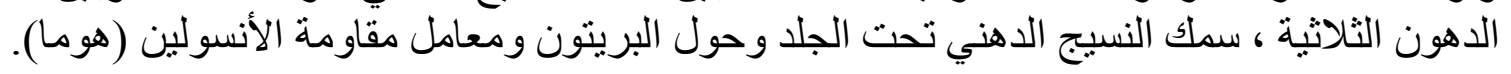

وتوصي الدر اسة باستخدام الموجات الصوتية كوسيلة فحص آمنة ورخيصة لتحديد سمك النسيج الدهني

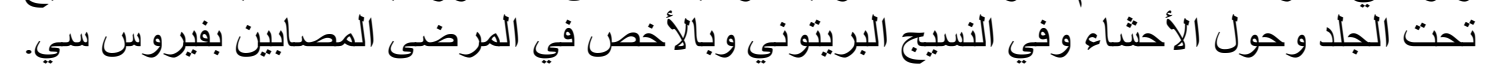

